\title{
Pengembangan Modul Kecerdasan Spiritual Sebagai Media Layanan Bimbingan dan Konseling Pribadi pada Siswa
}

\author{
Nurhan G Asi ${ }^{1}$, Rena Madina ${ }^{2}$, Irvan Usman ${ }^{3}$ \\ Jurusan Bimbingan dan Konseling, Fakultas Ilmu Pendidikan, Universitas Negeri Gorontalo, Indonesia ${ }^{1,2,3}$ \\ nursella695@gmail.com
}

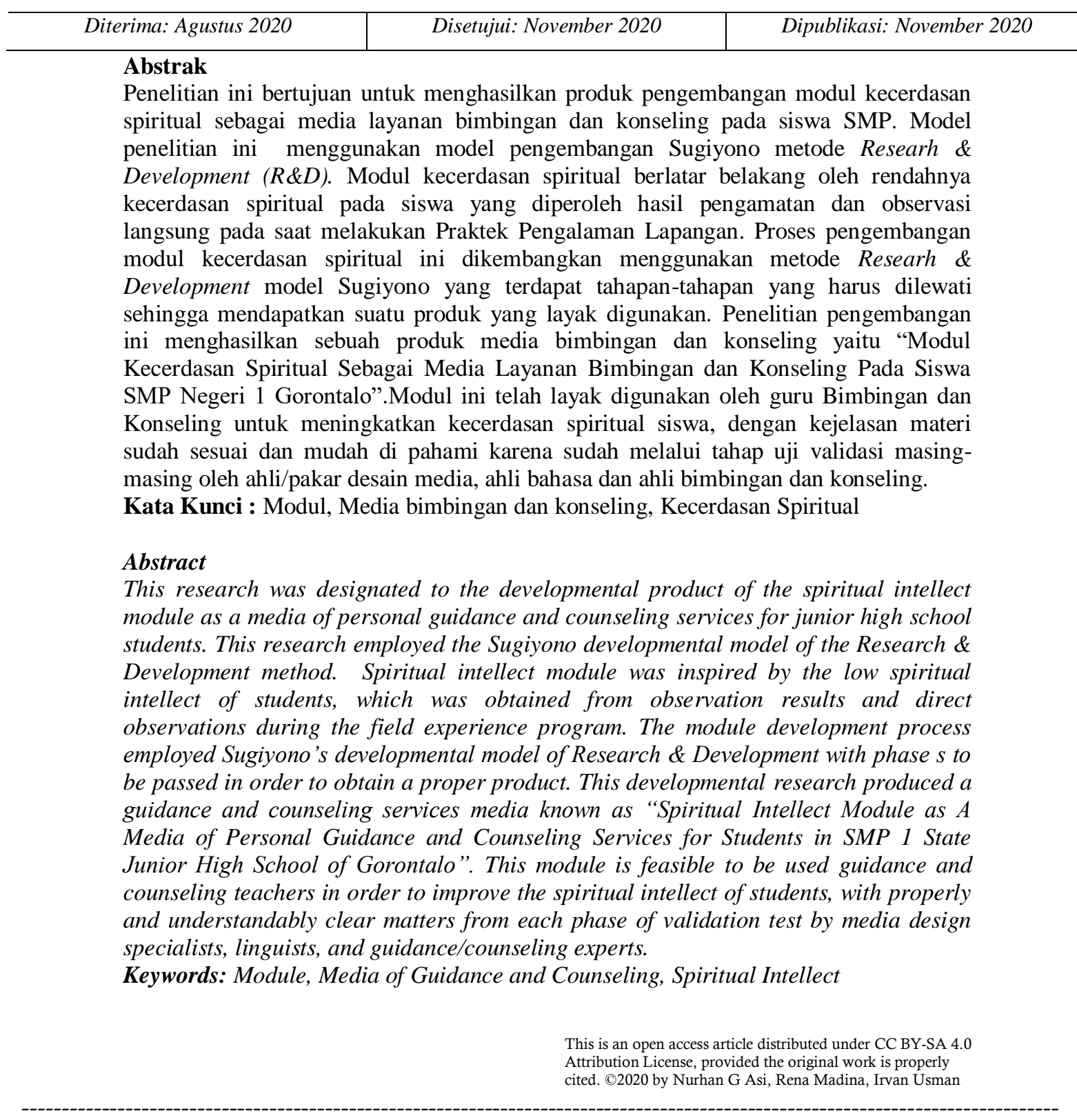

\section{PENDAHULUAN}

Pada hakikatnya manusia adalah salah satu makhluk ciptaan Allah SWT yang memiliki peranan penting dalam kehidupan dimuka bumi. Sebagai hamba Allah maka tugas utama manusia adalah beribadah dan menyembah Allah SWT, menjalani segala 
perintah-Nya dan menjauhi larangannya. Sebagaimana disebutkan dalam firman Allah SWT : "Tidaklah Aku ciptakan jin dan manusia, melainkan supaya mereka menyembah Aku"(Q.S Adz Zariat : 56). Dalam ayat tersebut sudah jelas bahwa manusia diciptakan oleh Allah semata-mata hanya untuk menyembah kepada Allah. Manusia dalam hal ini adalah peserta didik seharusnya sudah menyadari tugas mereka sebagai hamba Allah tersebut.

Peserta didik khususnya tingkat SMP umumnya berada pada remaja awal yaitu berusia 12 hingga 14 tahun. Sarwono (Padmomarto, 2014:16) Remaja merupakan periode yang penuh gejolak emosi dan tekanan jiwa sehingga remaja mudah berperilaku menyimpang dari aturan dan norma sosial yang berlaku dimasyarakat. Lebih lanjut Hall (Padmomartono, 2014:16) menyatakan bahwa masa remaja merupakan masa penuh gejolak emosi sehingga remaja mudah terpengaruh/diombang-ambingkan oleh lingkungan. Muncul rasa kecewa dan menderita, meningkat konflik dan krisis penyesuaian, remaja sibuk dengan impian dan khayalan, pacar dan cinta, rasa terasing, serta dihadapkan pada tuntutan yang melampaui kapasitas untuk memikulya.

Pada usia remaja lingkungan sangat berpengaruh bagi peserta didik, terutama teman sebaya ataupun orang-orang yang dianggap idola atau panutan. Pada situasi seperti itu maka diharapkan peserta didik mampu mengendalikan perilaku dan mempertimbangkan semua kemungkinan untuk menyelesaikan suatu masalah serta mempertanggung-jawabkannya. Peseta didik sebaiknya juga memiliki kecerdasan spiritual yang baik dan memadai. Adapun menurut Agustian (2001:57) menyatakan bahwa kecerdasan spiritual adalah suatu kemampuan untuk memberi makna ibadah terhadap setiap perilaku dan kegiatan, melalui langkah-langkah dan pemikiran yang bersifat fitrah, menuju manusia yang seutuhnya (hanif) dan memiliki pola pemikiran tauhid (integralistik) serta berprinsip bahwa "hanya karena Tuhan" atau kegiatan yang kita lakukan merupakan ibadah kepada Tuhan. Dengan demikian kecerdasan spiritual haruslah disandarkan kepada Tuhan dalam segala aktivitas kehidupan untuk mendapatkan suasana ibadah dalam aktivitas manusia.

Kecerdasan spiritual merupakan faktor penting untuk remaja dalam membentuk diri yang berkarakter, Melalui kecerdasan spiritual inilah akan membentuk karakter yang baik bagi peserta didik disekolah. Namun fenomena yang terjadi saat ini, tidak sedikit siswa yang memiliki kecerdasan spiritual yang rendah. Situasi ini teramati khususnya pada saat peneliti melakukan Praktek Pengalaman Lapangan (PPL) di SMP Negeri 1 Gorontalo, dimana siswa sering berkelahi dengan teman sebaya, banyak yang tidak melaksanakan sholat, pacaran dibawah umur, sering berkata kasar dan merokok bagi anak laki-laki. Hal ini menunjukan rendahnya kecerdasan spiritual peserta didik disekolah tersebut, karena ciri-ciri orang yang memiliki kecerdasan menurut Khavari (Masaong \& Tilome, 2014:104) terdiri atas tiga aspek yaitu: a) Kecerdasan spiritual dipandang dari sudut spirutualkeagamaan (relasi vertikal manusia dengan Tuhan) yang mencakup, yaitu: frekuensi doa, makhluk spiritual, kecintaan pada Tuhan YME yang bersemayam dalam hati, dan rasa syukur kehadirat-Nya; b) Kecerdasan spiritual dipandang dari segi relasi sosial-keagamaan sebagai konsekuensi logis relasi spiritual-keagamaan. Artinya, kecerdasan spiritual harus merefleksikan pada sikap-sikap sosial yang menekankan segi kebersamaan dan kesejahteraan sosial (sosial walfare) yaitu: ikatan kekeluargaan antar sesama, peka 
terhadap kesejahteraan orang lain, peka terhadap binatang-binatang, dan sikap dermawan; c) Kecerdasan spiritual dipandang dari sudut etika sosial yang dapat menggambarkan tingkat etika sosial seseorang sebagai cermin kadar kualitas kecerdasan spiritual yaitu: ketaatan kita pada etika moral, kejujuran, amanah, dapat dipercaya, sikap sopan, toleran, anti kekerasan.

Permasalahan ini menunjukan pentingnya untuk meningkatkan kecerdasan spiritual peserta didik disekolah, sehingga peserta didik menyadari bahwa mereka adalah mahkluk Allah yang harus menjalankan segala perintah-Nya dan menjauhi larangan-Nya. Peserta didik juga lebih mampu berfikir cerdas dan bertindak bijak serta bisa menjadi lebih menjunjung tinggi nilai-nilai moral dan etika dalam pergaulan. Berkenaan dengan permasalahan rendahnya kecerdasan spiritual siswa tersebut, maka upaya guru Bimbingan dan Konseling untuk meningkatkan kecerdasan spiritual siswa harus dioptialkan. Salah satu cara untuk dapat memberikan pemahaman kepada siswa lebih dalam mengenai kecerdasan spiritual selain melalui buku-buku pelajaran juga melalui pemberian layanan bimbingan oleh guru Bimbingan dan Konseling. Menurut Daryanto \& Farid (2015:5) Bimbingan dan konseling merupakan salah satu komponen dalam satuan sistem pendidikan khususnya di sekolah, guru sebagai salah satu pendukung unsur pelaksana pendidikan yang mempunyai tanggung jawab sebagai pendukung pelaksana layananan bimbingan pendidikan di sekolah, dituntut memiliki wawasan yang memadai terhadap konsep-konsep dasar bimbingan dan konseling di sekolah.

Pemberian layanan bimbingan dan konseling di SMP untuk membantu siswa dalam pengembangan pribadi, salah satunya pengembangan kecerdasan spiritual adalah layanan bimbingan dan konseling pribadi. Hal ini sesuai dengan tujuan pemberian layanan yang terkait dengan aspek pribadi-sosial menurut Yusuf \& Juntika (2012:14) yaitu (1) Memiliki komitmen yang kuat dalam mengamalkan nilai-nilai keimanan dan ketakwaan kepada Tuhan Yang Maha Esa, baik dalam kehidupan pribadi, keluarga, pergaulan dengan teman sebaya, sekolah, tempat kerja, maupun masyarakat pada umumnya; (2) Memiliki sikap toleransi terhadap umat beragama lain, dengan saling mengormati dan memelihara hak dan kewajibannya masing-masing, memiliki pemahaman tentang irama kehidupan yang bersifat fluktuatif antara yang menyenangkan (anugrah) dan tidak menyenangkan (musibah), serta mampu meresponnya secara positif sesuai dengan ajaran agama yang dianut; (3) Memiliki pemahaman dan penerimaan diri secara objektif dan konstruktif, baik yang terkait keunggulan maupun kelemahan; baik fisik maupun psikis; (4)Memiliki sikap positif atau respek terhadap diri sendiri dan orang lain; (5) Memiliki kemampuan melakukan pilihan secara sehat; (6) Bersikap respek terhadap orang lain, menghargai atau menghormati orang lain, tidak melecehkan martabat orang lain; (7) Memiliki rasa tanggung jawab, yang diwujudkan dalam bentuk komitmen terhadap tugas atau kewajibannya; (8) Memiliki kemampuan berinteraksi social (human relation-ship), yang diwujudkan dalam bentuk hubungan persahabatan, persaudaraan, atau silaturahim dengan sesama manusia; (9) Memiliki kemampuan dalam menyelesaikan konflik (masalah) baik bersifat internal (dalam diri sendiri) maupun dengan orang lain; (10) Memiliki kemampuan untuk mengambil keputusan secara efektif. 
Dalam rangka memudahkan konselor memberikan layanan bimbingan dan konseling pribadi untuk meningkatkan kecerdasan spritual kepada siswa, maka diperlukan media yang dapat membantu proses pemberian layanan. Menurut Rahim (2011:14) mengemukakan bahwa media merupakan salah satu fakor penentu keberhaslan layanan bimbingan dan konseling. Sehingga peneliti tertarik untuk mengembangkan media modul agar bisa digunakan oleh guru Bimbingan dan Konseling dalam memberikan layanan. Hal dikarenakan media modul ini bisa memuat banyak informasi-informasi terkait dengan pembelajaran, dapat memotivasi siswa untuk belajar mandiri, dengan media modul ini juga siswa dapat mengukur atau mengevaluasi sendiri hasil belajarnya.

Adapun menurut Sukiman (2012:133) bahwa dalam pengajaran modul sangat dimungkinkan: 1) adanya peningkatan motivasi belajar secara maksimal, 2) adanya peningkatan kreaktivitas guru dalam menyiapkan alat dan bahan yang diperlukan dan pelayanan individual yang lebih mantap, 3) dapat mewujudkan prinsip maju berkelanjutan secara tidak terbatas, 4) dapat mewujudkan belajar yang lebih berkonsentrasi. Senada dengan pendapat tersebut media modul juga mengarahkan siswa untuk belajar mandiri dan aktifsehingga diharapkan dapat memperoleh pemahaman dan pengetahuan baru sesuai dengan tujuan yang ingin dicapai (Tuasikal, Mudjiran, \& Nirwana, 2016). Disamping itu, rendahnya kecerdasan spiritual yang ditunjukkan oleh; 1) siswa malas melaksanakan sholat, 2) siswa sering berkelahi dengan teman sebaya, 3) siswa pacaran dibawah umur, 4) siswa sering berkata kasar, 5) siswa merokok bagi anak laki-laki

Berdasarkan latar belakang dan identifikasi masalah yang ditemui dalam penelitian ini maka tujuan penelitian ini adalah mengembangkan modul kecerdaan spiritual sebagai meda laayanan bimbingan dan konseliing prbadi pada siswa SMP.

\section{METODE PENELITIAN}

Penelitian ini dilaksanakan di SMP Negeri 1 Kota Gorontalo tahun 2020. Fokus yang diteliti dalam penelitian ini yaitu pengembangan modul kecerdasan spiritual sebagai media bimbingan dan konseling pribadi pada siswa Sekolah Menengah Pertama (SMP). Subjek penelitian ini adalah 1 orang ahli bimbingan dan konseling, 1 orang ahli bahasa, 1 orang ahli desain yang dapat menilai kelayakan modul yang akan digunakan serta 3 orang guru bimbingan dan konseling SMP.

Penelitian pengembangan ini menggunakan pengembangan model Sugiyono. Dalam penelitian ini prosedur penelitian yang digunakan berdasarkan prosedur penelitian dan pengembangan menurut Sugiyono (2016:408) ada sepuluh langkah dalam penelitian pengembangan, yakni: (1) Potensi dan masalah; (2) Mengumpulkan informasi; (3) Desain produk; (4) Validasi desain; (5) Perbaikan desain; (6) Uji coba produk; (7) Revisi produk; (8) Uji coba pemakaian; (9) Revisi produk; dan (10) Pembuatan produk masal. Namun prosedur penelitian yang dilakukan peneliti dalam pengembangan yang dikembangkan oleh Sugiyono tersebut dengan pembatasan. Penerapan langkah-langkah pegembangannya disesuaikan dengan kebutuhan peneliti. Langkah-langkah tersebut disederhanakan sampai pada langkah 6 (enam) langkah pengembangan yaitu: karena fokus penelitian ini bertujuan untuk menciptakan produk berupa modul kecerdasan spiritual. 


\section{Potensi dan Masalah}

Pada proses awal ini, peneliti mengamati masalah yang terjadi di lapangan selama mengikuti PPL (Praktek Pengalaman Lapangan) di SMP Negeri 1 Gorontalo, dimana siswa sering berkelahi dengan teman sebaya, sering ribut pada waktu sholat, ribut pada waktu sholat, pacaran dibawah umur, sering berkata kasar, dan merokok bagi anak laki-laki. Hal ini menunjukan bahwa peserta didik di sekolah tersebut sedang krisis kecerdasan spiritual, dimana mereka belum menyadari bahwa mereka adalah makhlul Allah yang harus menjalankan perintah-Nya dan menjauhi segala larangan-Nya. Seseorang yang memiliki kecerdasan spiritual tentunya lebih mampu berfikir cerdas dan bertindak bijak, ia bisa menjadi lebih menjunjung tinggi nilai-nilai moral dan etika dalam pergaulan, sehingga kecerdasan spiritual dalam diri setiap remaja perlu diperhatikan. Dengan demikian salah satu cara untuk memberikan pemahaman kepada siswa lebih dalam mengenai kecerdasan spiritual selain melalui buku-buku pelajaran juga melalui pemberian layanan bimbingan dan konseling oleh guru bimbingan dan konseling disekolah tersebut.

\section{Pengumpulan Informasi}

Pada tahap ini, berdasarkan pengamatan peneliti yang terjadi pada saat mengikuti PPL (Praktek Pengalaman Lapangan) maka yang dilakukan peneliti yakni mengumpulkan informasi-informasi mengenai kecerdasan spiritual. Tahap ini dilakukan agar peneliti memiliki gambaran dalam penyusunan modul.

\section{Desain Produk}

Pada tahap pengembangan ini peneliti mulai merancang produk awal modul kecerdasan spiritual sebagai media layanan bimbingan dan konseling pribadi di SMP. Pada tahap ini peneliti mulai menyusun draf modul kecerdasan spiritual yang meliputi; penentuan konsep desain, penentuan konsep isi, serta penentuan materi. Modul kecerdasan spiritual yang dikembangkan ini dibuat dengan menampilkan penuh warna dan gambargambar yang sesuai dengan isi materi.

\section{Validasi Desain}

Pada tahap ini, peneliti melakukan validasi ahli yaitu validasi ahli bimbingan dan konseling, validasi ahli bahasa, validasi ahli desain. Validasi ahli ini dilakukan untuk menilai bagian isi/materi, desain modul serta penggunaan bahasa yang ada dalam modul.

\section{Revisi Desain}

Berdasarkan hasil yang diperoleh pada kegiatan validasi ahli mengenai draf modul, maka dilakukan revisi terhadap beberapa aspek-aspek yang telah dinilai oleh validator dan perlu diberbaiki kembali dalam rangka menyempurnakan hasil produk akhir modul kecerdasan spiritual.

\section{Uji Coba Produk}

Uji coba produk modul kecerdasan spiritual, dilakukan dibeberapa sekolah menengah pertama yakni SMP Negeri 1 Gorontalo, SMP Negeri 6 Gorontalo, SMP Negeri 7 Gorontalo. Tujuan uji coba produk ini adalah untuk mengetahui apakah modul ini mudah dipahami, layak dan dapat digunakan oleh guru bimbingan dan konseling atau tidak. Pelaksanaan uji coba produk dilakukan dengan cara memberikan instrumen uji coba produk modul yang akan dinilai kepada guru bimbingan dan konseling sebagai sasaran 
penggunaan modul tersebut. Guru BK akan membaca buku tersebut kemudian mengisi instrumen sesuai dengan penilaiannya.

\section{HASIL TEMUAN}

Deskripsi hasil penelitian pengembangan ini mengacu pada tujuan penelitian yaitu mengembangkan modul kecerdasan spiritual sebagai media layanan bimbingan dan konseling pribadi pada siswa SMP. Secara khusus dilaksanakannya penelitian ini, yaitu:

a. Mengembangkan draf modul kecerdasan spiritual sebagai media layanan bimbingan dan konseling pribadi pada siswa SMP.

b. Mengembangkan instrumen validasi ahli meliputi; 1. Ahli bimbingan dan konseling, 2. Ahli bahasa Indonesia 3. Ahli desain media.

c. Melaksanakan validasi ahli dan melakukan revisi.

d. Melaksanakan uji coba produk.

e. Menghasilkan produk akhir dari hasil revisi.

Berikut merupakan penilaian dan analisis tentang hasil penelitian pengembangan modul kecerdasan spritual;

\section{Anlisis Uji Kelayakan Ahli Bimbingan dan Konseling}

Validasi ahli bimbingan dan konseling dilakukan untuk menilai bagian isi/materi yang ada dalam modul. Ahli yang melakukan validasi adalah Bapak Kadir Husain, M.Pd, Kons. Berdasarkan data yang diperoleh pada kegiatan validasi ahli mengenai draf modul, maka dilakukan revisi terhadap beberapa aspek-aspek yang telah dinilai oleh validator dan perlu diberbaiki kembali dalam rangka menyempurnakan hasil produk akhir modul kecerdasan spiritual. Berikut adalah aspek penilaian dari validasi ahli yang dijabarkan pada Tabel 1 di bawah ini.

\section{Tabel 1 Penilaian Modul Kecerdasan Spiritual oleh Ahli Bimbingan dan Konseling}

\begin{tabular}{lll}
\hline \multicolumn{3}{c}{ Validasi Ahli Bimbingan dan Konseling } \\
\hline No. & \multicolumn{1}{c}{ Aspek Penilaian } & Keterangan \\
\hline 1. & Kesesuaian judul modul dan materi & Sudah sesuai \\
2. & Penjelasan materi & Sudah sesuai \\
3. & Daftar rujukan & Sudah sesuai \\
4. & Modul dapat membantu guru memberikan layanan untuk & Sudah sesuai \\
& meningkatkan kecerdasan spiritual siswa & \\
5. & Isi modul mudah dimengerti & Sudah sesuai \\
6. & Modul dapat dijadikan sebagai media bimbingan dan & Sudah sesuai \\
& konseling pribadi bagi siswa & \\
7. & Kelayakan materi dalam modul & Sudah sesuai \\
8. & Pernyataan pada soal latihan disetiap kegiatan layanan & Sudah sesuai \\
\hline
\end{tabular}


Berdasarkan data dari hasil penilaian ahli bimbingan dan konseling bahwa modul kecerdasan spiritual sebagai media layanan bimbingan dan konseling pribadi pada siswa layak digunakan karena penjelasan materi sudah sesuai, materi dalam modul mudah dimengerti, sehingga dapat membantu guru bimbingan dan konseling dalam memberikan layanan. Beberapa saran diberikan untuk merevisi produk tersebut yakni; 1) Judul depan dan anak judul jangan dipisah, kalau perlu menyatu tetapi dibatasi/diletakan dalam kurung, 2) Perlu diperkaya rujukan, 3) Kunci jawaban ditaruh dilampiran terakhir, 4) Sebaiknya tugas atau pertanyaan dibuat dalam bentuk pilihan ganda atau soal objektif supaya mudah diperiksa/dinilai.

\section{Anlisis Uji Kelayakan Ahli Bahasa}

Validasi ahli bahasa dilakukan untuk menilai penggunaan bahasa dalam modul. Ahli yang melakukan validasi adalah Ibu Dra. Dajani Suleman, M.Hum. Berdasarkan data yang diperoleh pada kegiatan validasi ahli mengenai draf modul, maka dilakukan revisi terhadap beberapa aspek-aspek yang telah dinilai oleh validator dan perlu diberbaiki kembali dalam rangka menyempurnakan hasil produk akhir modul kecerdasan spiritual. Berikut adalah aspek penilaian ahli yang dijabarkan pada Tabel 2 di bawah ini.

Tabel 2. Penilaian Modul Kecerdasan Spiritual oleh Ahli Bahasa Indonesia

\begin{tabular}{lll}
\hline \multirow{2}{*}{ No. } & \multicolumn{2}{c}{ Validasi Ahli Bahasa Indonesia } \\
\cline { 2 - 3 } 1. & Bentuk huruf dan tulisan pada sampul & Keterangan \\
2. & Kesesuaian teknik dan cara penulisan dengan kaidah & Sudah sesuai \\
& penulisan yang benar & Sudah sesuai \\
3. & Kesesuaian antara isi modul dan tema & \\
4. & Bahasa modul yang digunakan sesuai dengan bahasa modul & Sudah sesuai \\
& pada umumnya & Sudah sesuai \\
5. & Ukuran huruf pada modul & \\
6. & Model tulisan pada modul & Sudah sesuai \\
7. & Kesesuaian ukuran huruf & Sudah sesuai \\
8. & Kesesuaian antara gambar dalam modul dengan tema & Sudah sesuai \\
9. & Kesesuaian warna table dalam modul & Sudah sesuai \\
\hline
\end{tabular}

Berdasarkan data dari hasil penilaian ahli bahasa bahwa modul kecerdasan spiritual sebagai media layanan bimbingan dan konseling pribadi pada siswa layak digunakan karena bahasa yang digunakan dalam modul ini bahasanya sederhana, kata-katanya mudah dipahami dan rangkaian kalimat demi kalimat sangat komunikatif artinya tidak memuat makna yang berlebihan. Beberapa saran diberikan untuk merevisi produk tersebut yakni; 1) warna tulisan pada sampul dipilih warna yang serasi dengan warna dasar pada sampul 
depan, supaya huruf-hurufnya mudah dibaca, 2) masih ditemukan teknik dan cara penulisan dalam modul yang kurang tepat seperti pada pilihan kata, penulisan 'di' sebagai penunjuk tempat dan bukan penunjuk tempat, 3) hal-hal atau topik-topik yang dianggap penting itu sebaiknya ditebalkan, 4) dituliskan kegiatan apa dibawah gambar pada setiap pelaksanaan layanan.

\section{Anlisis Uji Kelayakan Ahli Desain Media}

Validasi ahli desain media dilakukan untuk menilai desain modul. Ahli yang melakukan validasi adalah Bapak Moh. Rizki Djibran, S.Pd, M.Pd. Berdasarkan data yang diperoleh pada kegiatan validasi ahli mengenai draf modul, maka dilakukan revisi terhadap beberapa aspek-aspek yang telah dinilai oleh validator dan perlu diberbaiki kembali dalam rangka menyempurnakan hasil produk akhir modul kecerdasan spiritual. Berikut adalah data yang diperoleh dari validasi ahli yang dijabarkan pada tabel dibawah ini.

Tabel 3. Penilaian Modul Kecerdasan Spiritual oleh Ahli Desai Media

\begin{tabular}{lll}
\hline & \multicolumn{2}{c}{ Validasi Ahli Desain Media } \\
\cline { 2 - 3 } No & \multicolumn{1}{c}{ Aspek Penilaian } & Keterangan \\
\hline 1. & Desain sampul depan dan belakang & Sudah sesuai \\
2. & Gambar pada sampul depan & Sudah sesuai \\
3. & Bentuk huruf & Sudah sesuai \\
4. & Kesesuaian antara gambar dalam modul dan materi & Sudah sesuai \\
5. & Pemilihan warna pada modul & Sudah sesuai \\
6. & Kesesuaian warna pada table & Sudah sesuai \\
7. & Tampilan fisik modul & Sudah sesuai \\
\hline
\end{tabular}

Berdasarkan data dari hasil penilaian ahli desain bahwa modul kecerdasan spiritual sebagai media layanan bimbingan dan konseling pribadi pada siswa layak digunakan tampilan fisik sudah layak dan menarik. Beberapa saran diberikan untuk merevisi produk tersebut yakni; 1) untuk bab judul bab disesuaikan spasinya dengan spasi huruf pada paragraf, tapi kegiatan layanan dibuat huruf besar, 2) tata letak gambar terlalu monoton sebaiknya lebih bervariasi, 3harus diperhatikan konsisten warna pada halaman-halaman dll, 4) sebaiknya halamannya diprint bolak-balik.

\section{Hasil Uji Coba Produk}

Uji coba produk modul kecerdasan spiritual, dilakukan dibeberapa sekolah menengah pertama yakni SMP Negeri 1 Gorontalo, SMP Negeri 6 Gorontalo, SMP Negeri 7 Gorontalo. Tujuan uji coba produk ini adalah untuk mengetahui apakah modul ini mudah dipahami, layak dan dapat digunakan oleh guru bimbingan dan konseling atau tidak. Pelaksanaan uji coba produk dilakukan dengan cara memberikan instrumen uji coba produk modul yang akan dinilai kepada guru bimbingan dan konseling sebagai sasaran penggunaan modul tersebut. Guru BK akan membaca buku tersebut kemudian mengisi instrumen sesuai dengan penilaiannya. 


\section{Hasil Uji Coba Produk Modul di SMP Negeri 1 Gorontalo}

Uji coba produk modul di SMP Negeri 1 Gorontalo dilakukan oleh salah satu guru BK disekolah tersebut, yakni oleh Bapak Zulkifli B. Ointu, S.Pd. Hasil uji coba produk modul oleh guru bimbingan dan konseling di SMP Negeri 1 Gorontalo memperoleh data $100 \%$ dengan kategori cukup baik dengan beberapa masukan yaitu: beberapa materi kegiatan layanan dalam modul tersebut perlu disertai beberapa gambar agar lebih menarik dan lebih mudah dipahami.

\section{Hasil Uji Coba Produk Modul di SMP Negeri 6 Gorontalo}

Uji coba produk modul di SMP Negeri 6 Gorontalo dilakukan oleh salah satu guru BK disekolah tersebut, yakni oleh Bapak Weni Tomayahu, S.Pd. Hasil uji coba produk modul oleh guru bimbingan dan konseling di SMP Negeri 6 Gorontalo memperoleh data 100\% dengan kategori cukup baik dengan beberapa masukan yaitu: 1) Gambar visualisasi perlu ditambah, 2) Pada setiap layanan alangkah baiknya dicantumkan langkah-langkah bimbingan biar nampak perbedaan seperti pada layanan bimbingan kelompok dengan konseling kelompok dilihat dari visualisasinya sama.

\section{Hasil Uji Coba Produk Modul di SMP Negeri 7 Gorontalo}

Uji coba produk modul di SMP Negeri 7 Gorontalo dilakukan oleh salah satu guru BK disekolah tersebut, yakni oleh Ibu Ha. Emy N. Kasim, S.Pd. Hasil uji coba produk modul oleh guru bimbingan dan konseling di SMP Negeri 7 Gorontalo memperoleh data $100 \%$ dengan kategori cukup baik.

\section{PEMBAHASAN}

Modul merupakan bahan ajar cetak yang dirancang secara sistematis yang bertujuan untuk membantu guru dalam proses pembelajaran. Darmiatun (2013:9) mengungkapkan bahwa modul merupakan salah satu bentuk bahan ajar yang dikemas secara utuh dan sistematis, didalamnya memuat seperangkat pengalaman belajar yang terencana dan didesain untuk membantu peserta didik menguasai tujuan belajar yang spesifik. Lebih lanjut Mulyasa (Budiono \& Hadi, 2006:80) mengungkapkan bahwa modul merupakan paket belajar mandiri yang meliputi serangkaian pengalaman belajar yang direncanakan serta dirancang secara sistematis untuk membantu siswa mencapai tujuan yang besar. Kualitas modul dapat dilihat dari beberapa aspek yaitu: 1) aspek kelayakan isi, 2) aspek kelayakan bahasa, 3) aspek kelayakan penyajian, 4) aspek kelayakan kegrafikan.

Berdasarkan uraian pendapat ahli, maka modul adalah bahan ajar cetak yang dirancang untuk dapat dipelajari secara mandiri oleh peserta didik dan dikemas secara sistematis, didalamnya memuat seperangkat pengalaman belajar yang terencana serta kualitas modul dapat dilihat dari aspek kelayakanisi, bahasa, penyajian, dan kegrafikan.

Modul kecerdasan spiritual pada siswa dilatar belakangi oleh rendahnya kecerdasan spiritual siswa yang diperoleh dari hasil pengamatan dan observasi langsung. Proses pengembangan modul kecerdasan spiritual dikembangkan menggunakan model Sugiyono metode Researh \& Development $(R \& D)$ yang di dalamnya terdapat tahap-tahap yang harus dilewati sehingga menjadi produk modul yang layak digunakan.

Modul merupakan media untuk belajar mandiri sehingga dapat digunakan untuk belajar sendiri. Adapun menurut Sukiman (2012: 133) bahwa dalam pengajaran modul 
sangat dimungkinkan: 1) adanya peningkatan motivasi belajar secara maksimal, 2) adanya peningkatan kreaktivitas guru dalam menyiapkan alat dan bahan yang diperlukan dan pelayanan individual yang lebih mantap, 3) dapat mewujudkan prinsip maju berkelanjutan secara tidak terbatas, 4) dapat mewujudkan belajar yang lebih berkonsentrasi.

Deskripsi hasil penelitian pengembangan ini mengacu pada tujuan penelitian yaitu mengembangkan modul kecerdasan spiritual sebagai media layanan bimbingan dan konseling pribadi pada siswa SMP. Secara khusus dilaksanakannya penelitian ini, yaitu:

a. Mengembangkan draf modul kecerdasan spiritual sebagai media layanan bimbingan dan konseling pribadi pada siswa SMP.

b. Mengembangkan instrumen validasi ahli meliputi; 1. Ahli bimbingan dan konseling, 2. Ahli bahasa Indonesia 3. Ahli desain media.

c. Melaksanakan validasi ahli dan melakukan revisi.

d. Melaksanakan uji coba produk.

e. Menghasilkan produk akhir dari hasil revisi.

\section{SIMPULAN}

Penelitian pengembangan ini menghasilkan sebuah produk sebagai media layanan bimbingan dan konseling yaitu "Modul Kecerdasan Spiritual Sebagai Media Layanan Bimbingan dan Konseling Pribadi pada Siswa untuk Guru Bimbingan dan Konseling SMP”. Media ini sudah layak digunakan sebagai media dalam melaksanakan layanan bimbingan dan konseling di sekolah, bentuk serta isi modul jelas dan mudah dipahami karena Penelitian pengembangan ini menghasilkan produk sebagai media layanan bimbingan telah melalui tahap uji validasi ahli masing-masing pakar.

\section{DAFTAR PUSTAKA}

Agustian, A.G. (2001). Rahasia Sukses Membangun Kecerdasan Emosi dan Spiritual Berdasarkan 6 Rukun Iman dan 5 Rukun Islam. Jakarta: Arga Jakarta.

Budiono, E. \& Hadi, S. (2006). Penyusunan dan Penggunaan Modul Pembelajaran Berdasar Kurikulum Berbasis Kompetensi Sub Pokok Bahasan Analisa Kuantitatif Untuk Soal-Soal Dinamika Sederhana Pada Kelas X Semester 1 SMA. Jurnal Pendidikan Fisika Indonesia. Vol 4. No. 2. Diakses pada http://journal.unnes.ac.id>nju tanggal 21 Oktober 2019.

Darmiatun, S. (2013). Menyusun Modul Bahan Ajar Untuk Persiapan Guru Dalam Mengajar. Yogyakarta: Gava Media.

Daryanto \& Farid, M. (2015). Bimbingan Konseling Panduan Guru BK dan Guru Umum. Yogyakarta: Gava Media.

Masaong, K \& Arfan A.T. (2014). Keprmimpinan Pendidikan Berbasis Multiple Intelegence (Sinergi Kecerdasan Intelektual, Emosional dan Spiritual untuk Meraih Kesuksesan yang Gemilang). Bandung: Alfabeta. 
Padmomartono, S. (2014). Konseling Remaja. Yogyakarta: Penerbit Ombak.

Rahim, M. 2011. Pengembangan Buku Saku Sebagai Media Bimbingan Belajar Siswa SMA. Di akses pada https://repository.ung.ac.id/karyailmiah/show/139/pengembanganbuku- saku-sebagai-media-bimbingan-belajar-siswa-sma.html tanggal 6 Juli 2020.

Sugiyono. (2016). Metode Penelitian Pendidikan; Pendekatan Kuantitatif, Kualitatif, dan $R \& D$. Bandung: Alfabeta.

Sukiman. (2012). Pengembangan Media Pembelajaran. Yogyakarta: Pedagogia.

Tuasikal, J. M. S., Mudjiran, M., \& Nirwana, H. (2016). Pengembangan Modul Bimbingan dan Konseling untuk Meningkatkan Kemampuan Komunikasi Interpersonal Siswa. Konselor, 5(3), 133-138.

Yusuf, S \& Nurihsan, A.J. (2012). Landasan Bimbingan dan Konseling. Bandung: Remaja Rosdakarya Offset. 